\title{
Deposit Insurance and Bank Risks in Vietnam
}

\author{
Pham Thi Chi \\ Financial Department, Faculty of Management and Tourism \\ Hanoi University, Km9 Nguyen Trai, Thanh Xuan, Ha Noi, Viet Nam \\ E-mail: phamchi105@gmail.com
}

PhD. Dao Thanh Binh (Corresponding author)

Financial Department, Faculty of Management and Tourism

Hanoi University, Km9 Nguyen Trai, Thanh Xuan, Ha Noi, Viet Nam

Tel: 904-082-810 E-mail: binhdtt@ $@$ hanu.edu.vn

$\begin{array}{lc}\text { Received: February 29, } 2020 \quad \text { Accepted: March 21, } 2020 \quad \text { Published: March 26, } 2020 \\ \text { doi:10.5296/ber.v10i2.16750 } & \text { URL: https://doi.org/10.5296/ber.v10i2.16750 }\end{array}$

\begin{abstract}
The relationship between deposit insurance and banking risks has been widely studied, but has been the subject of relatively few empirical studies, especially for Vietnamese banking system. This research aims to explore the effect of deposit insurance on banks' risk taking in Vietnam. The paper employs 7 bank specific variables and 2 macroeconomic variables, as well the premium paid by banks as variables for the regression models used. The results suggest that deposit insurance does impact banks' risk taking incentive but it has different effects on each type of risk. It is concluded that credit, default and leverage risk are found to have a negative relationship with deposit insurance, while leverage and deposit insurance have a positive relationship, which may help banks and supervisors in their decision for the deposit risk premium. This paper contributes to the existing literature by help to understand the impact of deposit insurance on banks risk taking behavior in Vietnamese banks.
\end{abstract}

Keywords: Credit risk, Default risk, Deposit insurance, Leverage risk, Liquidity risk

\section{Introduction}

The Great Depression during 1929-1933 raises the need to develop a financial institution specialized in protecting and maintaining the confidence of depositors and coordinating with government agency to preserve financial system stability. The first deposit insurance scheme sponsored by the federal government was officially introduced in the US in 1933 with the 
establishment of the Federal Deposit Insurance Corporation. However, it was not until the last two decades that deposit insurance was studied comprehensively. The financial crisis that started in 1997 is one of the most significant economic events over the last 50 years. The waves of systemic banking crises have affected most of the countries around the world, regardless of developing or developed countries. World Bank (2001), using increases in the stock of public debt to GDP in the crisis year as a measure, figures out that total fiscal cost of Thailand and Korea during 1997 banking crises surpassed 30 percent of total GDP, while in Indonesia it is 50 percent of GDP.

Nevertheless, the cost of financial crises does not include fiscal cost only. It spreads out to many aspects of the economy. During the crisis, many banks, including those which were considered to be sound, have to face liquidity problem. Depositors may lose access to their funds and borrowers can lose access to credit. Some banks are forced into bankruptcy and investors lose their market confidence.

The goal of achieving and maintaining the soundness of financial system has become a top priority for policymakers. A "safety net" is established in almost every country to limit the likelihood of financial breakdown and its possible consequences which consists of deposit insurance system, lender-of-last-resort at the central bank, procedures for investigating and resolving bank insolvencies, strategies for regulating and supervising banks and provisions for accessing emergency assistance from multinational institutions, such as the IMF (Demirguc-Kunt and Kane, 2002). It has spread rapidly in recent years. According to the International Association of Deposit Insurers (IADI), an international organization established to contribute to the stability of financial systems by promoting international cooperation and to encourage wide international contact among deposit insurers and other interested parties, as of 31 March 2011, 111 countries have instituted some form of explicit deposit insurance compared to only 12 countries in 1974.

The primary mission of a deposit insurance scheme is to limit the risk of bank runs by guaranteeing that depositors receive some, or all, of their deposited funds with reasonable speed if their banks fail and become insolvent. It is supposed to reduce the likelihood and severity of bank runs during a financial crisis and thus can be a useful tool for governments to enhance the financial system and to protect depositors from huge losses by insolvent banks during crisis times. Moreover, deposit insurance can help to restore depositors' confidence and promote financial intermediary development by increasing opportunities for small banks to compete with larger institutions for deposits as deposit insurance addresses the depositors' concern about the fragility of small banks.

Despite the benefits of deposit insurance, it has also been subject to criticism. There has been a widespread consensus that because deposit insurance reduces the incentive of depositors to monitors banks, the existence of a deposit insurance scheme induces insured banks to take excessive risks. This side-effect of deposit insurance is referred to as "moral hazard" problem, which indicates that banks tend to take on risks that can be shifted to a deposit insurance fund.

International research on deposit insurance has proliferated over the last two decades. 
However, in Vietnam, despite the importance of deposit insurance, there is still a lack of studies on the impact of deposit insurance on the financial and banking system, more specifically, the relationship between deposit insurance scheme and bank risk taking activities. Most of the studies in this field only focus on theoretical part of deposit insurance, and lack of empirical evidence, hence not convincing enough. This research, using an empirical model, is targeted to develop a more complete study on the relationship between deposit insurance and banks' risk taking in Vietnam. This study seeks to answer the question regarding the relationship between deposit insurance and banking risks, with the support of empirical evidence.

The paper is structured as followed: The first section introduces the main topic of the research, the necessity of developing an empirical study on deposit insurance in Vietnam and methodology of the research. Section 2 reviews the theoretical and empirical framework on deposit insurance and banking risks. This part aims to give a comprehensive background about deposit insurance, current deposit insurance policy both internationally and in Vietnam. Section 3 states the hypothesis and the model. Last section provides results, implications of this research, and conclusion.

\section{Literature Review}

\subsection{Theoretical Framework on Rationale for Deposit Insurance}

The main activities of banks in financial markets are taking deposits from customers and making loans to those who are in need of money, or investing in potential projects. However, lenders tend to make short-term deposits while borrowers prefer long-term loans for investment. This maturity mismatch is the primary cause of banks' liquidity risks and it becomes a serious problem especially during financial crisis.

According to Diamond and Dybvig (1983), bank runs happen when depositors are afraid of losing their deposited amount, they find it best to withdraw their deposits prematurely if they expect others to do the same. This is due to the assumptions of first-come first-served basis and costly liquidation of the banks' long-term assets. On the contrary, if people believe that no panic will occur, only those who are really in need of money will withdraw their funds and those demands will be easily met by banks. With the existence of a deposit insurance scheme, depositors believe that their funds are safe no matter what other people do; they will not rush to the bank to withdraw money prematurely.

Demirguc-Kunt and Sobaci (2001) notes that deposit insurance or deposit guarantee is a complementary element in the financial safety net used by governments to maintain stable banking system and protect small investors in case of bank failures. Deposit guarantee can exist either as explicit deposit insurance, which are formal schemes enacted through legislation or implicit deposit guarantee system if there is no such formal schemes.

Likewise, Schich (2009) argues that without a financial safety net, a simple rumor of financial institutions having solvency or liquidity issues might cause depositors to withdraw their deposits before maturity and could potentially turn into a self-fulfilling full blown crisis. 
Market discipline increases the information available to the public by encouraging the release of timely information detailing a company's assets, liabilities and general financial information. This reduces the uncertainty and promotes the function of the market as an exchange between lenders and borrowers.

Market discipline becomes a topic of particular concern because of banking deposit insurance laws. Practically, most deposit insurance schemes are funded by the governments. Normally, bank managers have strong incentives to avoid risky loans and investments. However, government-funded deposit insurance reduces much of the risk to bankers, resulting in excessive bank risk taking. This constitutes a loss of market discipline. In order to offset this loss of market discipline, governments carry out regulations aimed at preventing banks from taking excessive risk. Today market discipline is introduced into the Basel II Capital Accord as a pillar of prudential banking regulation.

However, the competence of regulations aimed at introducing market discipline is questionable. The existence of financial bailouts provides implicit insurance schemes like "too-big-to-fail". In other words, a big bank is guaranteed that in any case, it will be rescued by central agencies for fear of financial contagion. As a result, depositors would not bother much to monitor bank activities under these favorable circumstances.

Moral hazard is the risk that a party to a transaction has not entered into the contract in good faith, has provided misleading information about its assets, liabilities or credit capacity, or has an incentive to take unusual risks in a desperate attempt to earn a profit before the contract settles.

A number of studies have analyzed the drawbacks of deposit insurance in terms of moral hazard. Boot and Greenbaum (1993) stated that as with any form of insurance, risk-sensitive and complete deposit insurance increases banks' incentives to act prudently and limits market discipline since depositors no longer have the incentive to control their banks. This means that risk is shifted on to the deposit insurer and there is a trade-off in the provision of deposit insurance. On the one hand, explicit deposit insurance can significantly lower the incidence of bank runs, as depositors are guaranteed to receive the promised payments. On the other hand, in case of not having been done carefully, deposit insurance increases risks in the financial system and may fuel bank crises by giving banks incentives to take excessive risks.

In a world without deposit insurance, banks always have to pay premium for any additional risks taken. The riskier the bank's investments are, the more premium depositors require the bank to pay. However, with the existence of a government-funded deposit insurance scheme, depositors will not demand a risk premium from banks because they know that the government will insure the repayment of their deposits, regardless whether the bank makes the loan. Therefore, deposit insurance gives banks incentives to take excessive risks, either by raising their leverage or making riskier loans, eventually increases the government's exposure to losses.

Despite the moral hazard in explicit deposit insurance, there are several ways in which the distortion introduced by risk-sensitive deposit insurance can be corrected, or at least limited. 
Allen et al. (2011) suggest three ways to constraint moral hazard. The first one is to implement a risk-sensitive pricing structure. If premium were risk sensitive, then deposit insurance would not entail incentive problems as premium would perfectly reflect the risk of banks' portfolios, thus removing any incentive to take additional risks. Nonetheless, implementing risk sensitive premium can be problematic because it requires that the regulators detect the risk of banks' portfolios or are able to encourage banks to reveal it without entailing too high costs. The second way to reduce the distortions caused by deposit insurance is to complement it with a proper regulatory framework. A solution that restores banks' cautious behavior is to require them to raise capital. Considering the fact that shareholders have to use their capital to repay depositors in case of bank failure, they no longer have the incentive to use depositors' fund for risky investments. Hence, a combination of deposit insurance and capital regulation may minimize the effect of moral hazard and allows the achievement of an efficient method to stabilize the banking system. Another way to solve the incentive problem arising from deposit insurance is through taxation of banks' liabilities. In fact, without bailouts, banks usually invest in short-term assets as a form of private insurance against runs.

\subsection{Empirical Framework}

Most researchers conducted on this subject tend to indicate that deposit insurance is responsible for the increase in risk taking activity in banks. Enkhbold (2013) uses a panel database of 401 banks in 31 Asian countries over the period from 2000 to 2010 to study the effects of deposit insurance on banks' risk-taking incentives. The result demonstrates that risk-taking incentives vary depending on bank size and risks. Additionally, differentiated premiums may not accurately reflect the level of risk that a bank carries. With the existence of a deposit insurance system, the pattern of the non-linear relationship between bank size and risk-taking considerably changes. The study points out that market discipline exercised by banks is stronger in the presence of mandatory deposit insurance scheme. Government-funded deposit insurance funds allow Asian banks to take a higher risk. A risk-based deposit insurance scheme functions more effectively in the countries with good regulatory framework and institutional quality. Enkhbold (2013) also concludes that the implementation of deposit insurance helps to stabilize the banking system but at the same time it also encourages banks to undertake excessive risks.

Demirguc-Kunt and Detragiache (2000) conduct an empirical investigation on the impact of deposit insurance on banking system stability, relying on a data base assembled at the World Bank which records the characteristics of deposit insurance systems around the world. Firstly, they test whether a zero-one dummy variable for the presence of explicit deposit insurance has a significant coefficient. The second test is designed to determine whether the impact of deposit insurance on bank stability depends on the quality of the regulatory environment. The research finds that explicit deposit insurance tends to be detrimental to bank stability. The impact is particularly more obvious in countries where bank interest rates are deregulated and where the institutional environment is unhealthy. Furthermore, the adverse effect of deposit insurance on bank stability seems to be stronger when a higher coverage is offered to depositors, when the scheme is funded, and when the scheme is managed by the government 
instead of the private sector.

Angkinand and Wihlborg (2010) tested the impact of deposit insurance coverage and banks' governance structures on banks' risk-taking in a cross-section time-series, as well as cross-section analysis using country-level data. The advantage of using country level data instead of data available on the bank level is that information about non-performing loans through the IMF's Financial Stability Reports can be obtained. The IMF data reflects information the IMF has gathered in addition to the data published by banks themselves, so it will be more accurate. The result suggests that the relationship between banks' risk taking and deposit insurance coverage can be described as U-shaped, particularly in countries with higher quality of governance. In fact, the deposit insurance coverage range varies widely among Asian and European countries. The research also demonstrates that while some countries would benefit by raising the coverage, some would have advantages if they decrease the coverage. The overall conclusion is that banks' risk taking is minimized at an intermediate level of deposit insurance coverage.

In a different perspective, Davis and Obasi (2009) explore microeconomic aspects of the deposit insurance - banking risks relationship. It takes in to account four of the five IMF core financial soundness indicators, using data from financial statements of 914 banks in 64 countries. Results, generated using Generalized Method of Moments, suggest that the presence of a deposit insurance scheme has no impact on the level of liquidity and the capital adequacy of banks. Instead, the effect of deposit insurance system on banking risks is demonstrated by its relationship with the asset quality of banks as captured by the total loans to total assets ratio and bank profitability as presented by the return on average assets. An optimal deposit insurance scheme might include features such as voluntary membership, no coinsurance, be unfunded, no cover for foreign currency deposits, and administered by a private sector manager with the insurance cost borne fully by the private sector.

Gropp and Vesala (2004) claim that deposit insurance may reduce moral hazard, if it leaves out non-deposit creditors. EU bank level data are used to test the model, the result suggests that explicit deposit insurance may serve as a commitment device to limit the safety net and permit monitoring by uninsured subordinated debt holders. They further find that the introduction of explicit deposit insurance tends to increase the share of insured deposits in banks' liabilities. The research emphasizes that the credibility of the deposit insurance system might be the key to the difference between the result from their study and the result of previous researches, which tend to concludes that deposit insurance increases moral hazard. Other studies which claim that a deposit insurance scheme raises banks' risk taking mostly use data from developing or emerging countries.

\subsection{Current Deposit Insurance Policy}

\subsubsection{International Deposit Insurance System}

The deposit insurance regulation was established in the USA before the Federation of Deposit Insurance Company (FDIC) - the first deposit insurance organization in the world - was founded in 1933. Since then, it has been amended many times to adapt to the change in 
economic conditions and to improve the effectiveness of FDIC.

In Russia and most European countries, deposit insurance regulation is also carried out before the establishment of deposit insurance organization. In addition to the deposit insurance regulation system of each country, the European Community carries out EU Directive in deposit insurance applied for all member countries.

In Asia, Korea enforces Depositor protection Law as a legal basis for deposit insurance system. Japan has deposit insurance regulation in accordance with the law system regulates activities of members in National financial safety net.

South East Asian countries which already have explicit deposit insurance system such as the Philippines, Indonesia, Malaysia have established deposit insurance regulation. Founded in 2005, Malaysian deposit insurance already had deposit insurance regulation with clear clauses on the functions, rights, obligations of deposit insurance organization and the relationship with other financial institutions.

Most deposit insurance organizations are structured as independent institution owned by the government. The tasks of these organizations (for example in Canada, Japan, Malaysia, Mexico, the United States) are often prescribed in law. Although this organizational model requires more concern than the other models, it allows the deposit insurance institution to perform assigned tasks in an efficient manner and best protect the interests of depositors.

A different form of deposit insurance organizations is non-profit institution founded and funded by a number of banks (for example in France, Argentina and Brazil). Despite being funded by the banks' capital and managed by those banks, common tasks of these organizations are also specified in law.

Each country has a different way of dividing responsibilities among agencies in national financial safety net, but in general, an effective financial safety net often includes components such as a safety management and surveillance division, the lender of last resort, deposit insurance organization and resolution mechanism for banks in trouble. In many countries, another government agency (usually the Ministry of Finance) also plays an important role in the safety net and is often responsible for the policy regarding financial sector. The members of the financial safety net aim to improve performance efficiency and stability of the banking system during normal periods as well as crisis.

The survey by Kunt (2000) shows that all deposit insurance organizations have been considered as a component of the financial safety net in that country, as a channel to stabilize the banking system alongside monitoring agencies and the only agency which has the function of protecting depositors.

\subsubsection{Vietnamese Deposit Insurance System}

The Deposit Insurance of Vietnam (DIV) is a state run financial institution set up under the Prime Minister's Decision No.218/1999/QD TTg dated November 9, 1999, with the mission of protecting the legitimate interests of depositors, and contributing to the maintenance of the stability of the insured institutions and the safe and sound development of banking 
operations.

Like the deposit insurance system of most countries in the world, DIV was launched with these main objectives: (1) To protect depositors with small amount of money and limited information on the institutions that receive deposits; (2) To contribute to the stability of the banking - financial system, prevent crashes in the system; (3) To improve the equal competitiveness among financial institutions and healthy development of the financial system. These three objectives are closely related and the objective of protecting the rights of depositors is considered as a top priority.

Some of the main tasks of DIV include: receiving, managing and using proper capital, land and other resources allocated by the government; fulfilling commitments on insurance payment to the depositors of any insured institution which shall be declared in written form by the relevant authorities to be insolvent; fulfilling commitments to the insured institutions and other commitments under DIV's jurisdiction.

Regarding the membership of deposit insurance, all financial institutions and institutions that are allowed to perform banking activities like receiving deposits from individuals and organizations are obliged to pay deposit insurance premium.

In Vietnam, the fixed deposit insurance coverage which is paid to all types of deposit including both the principal and return of one depositor is VND 50 million. As recommended by the IADI, deposit insurance coverage should be able to protect from $90 \%$ to $95 \%$ of depositors; and the ratio of "Coverage/GDP per capita" should be at least 2 and equivalent to the average of that in other countries with the same level of banking service development. However, because of the increase in Vietnam's GDP per capita, since 2011 the ratio of "Coverage/GDP per capita" has been less than 2 and only $85 \%$ of depositors are insured. The deposit insurance coverage in Vietnam is lower than the minimum level recommended by IADI. Judging from many different criteria, deposit insurance coverage of Vietnam is among the lowest group in Southeast Asia, which is detrimental to the domestic banks during integration period. This raises the need to increase deposit insurance coverage, thereby contributing to improve the effectiveness of deposit insurance policy.

Being aware of the importance of deposit insurance coverage, DIV has conducted surveys and proposed an increase in deposit insurance coverage to VND200 million; whereby over 90\% of depositors are insured, equivalent of 5 times GDP per capita at 31/12/2013. According to the DIV research team, VND200 million is more consistent with the international practices (based on the average of Southeast Asia, after taking into consideration inflation, GDP per capita, being in the process of bank restructure, risk level of the economy, etc.). This will also help people feel more secure when putting money in banks.

\section{Vietnamese deposit insurance fee}

Currently, deposit insurance fee for each quarter applied to all banks in Vietnam is calculated as follow:

$$
\mathrm{P}=((\mathrm{S} 0+\mathrm{S} 3) / 2+\mathrm{S} 1+\mathrm{S} 2) / 3 * 0.15 \% / 4
$$


In which: $\mathrm{P}$ is deposit insurance premium for current quarter, S0 is deposit balance of depositors qualified for deposit insurance at the beginning of previous quarter and S1, S2, S3: deposit balance of depositors qualified for deposit insurance at the end of the first, second, third month of previous quarter.

This fixed deposit insurance premium system has been opposed by many economists. There are a lot of arguments and recommendations with regard to the necessity of a risk-based deposit insurance premium system in Vietnam.

In the previous two sections, the rationality of deposit insurance as well as several previous studies relating to deposit insurance and banking risks, the overview of current foreign and local deposit insurance situations, have been presented. In the next section, the paper will present the quantitative model for deposit insurance in Vietnam with the statement of hypothesis, the database for the research drawn from financial statements of banks in Vietnam, securities companies and deposit insurance premium and the regression results for four different risk models.

\section{Quantitative Model for Deposit Insurance in Vietnam}

\subsection{Hypothesis of Relationships}

Research hypothesis: The presence of a deposit insurance scheme generates incentives that lead banks to take on excessive risks.

\subsection{Description of Variables}

Table 1. Descriptions of variables

\begin{tabular}{|l|l|l|}
\hline No & Variables & Definition \\
\hline & $\begin{array}{l}\text { Dependent variables }= \\
\text { Risk Variables Rt }\end{array}$ & $\begin{array}{l}\text { A set of dependent variables of risks } \\
\text { of individual banks }\end{array}$ \\
\hline 1 & Leverage risk $($ LEV $)$ & Book value of debt/Book value of total assets \\
\hline 2 & Liquidity risk $($ LIQ $)$ & \\
\hline 3 & Default risk $(D E F)$ & $1 /(1+12 *$ exp $(\mathrm{R}))$ \\
\hline 4 & Credit risk $($ CRE $)$ & Non-performing loans/Gross loans \\
\hline & Independent variables & \\
\hline & Bank variables $-\mathbf{X t}$ & Variables unique to the bank at the period t \\
\hline 1 & CAR & Capital adequacy ratio \\
\hline 2 & NII & Non-interest income/Gross income \\
\hline 3 & PRE & Annual deposit insurance premium/Total deposits \\
\hline 4 & ROA & Net income/Total assets \\
\hline 5 & ROE & Net income/Total equity \\
\hline 6 & TA & Total assets \\
\hline 7 & TDTA & Total customer deposits/Total assets \\
\hline & Country-specific variables - Mt & Country-specific variables at time t \\
\hline 8 & GDPG & Annual percentage change of real GDP \\
\hline 9 & RINT & Real interest rate \\
\hline
\end{tabular}




\subsubsection{Risk Variables}

The dependent variables are risk variables of individual banks. In this study, default risk, liquidity risk, credit risk and leverage risk are used as proxies to bank risks.

\section{Default risk}

By definition, default risk is the event in which companies or individuals will be unable to make the required payments on their debt obligations.

In the context of banking system in Vietnam, among all empirical studies on how to calculate business default probability, there is a superior approach by Dao and Dang (2010). The two researchers use a sample of 62 Vietnamese firms including commercial banks. The final estimation resulted from the model is:

$$
\mathrm{DEF}=1 /(1+12 * \exp (\mathrm{R}))
$$

In which, DEF is the bank default probability, a proxy of default risk and $\mathrm{R}$ is the bank credit scoring. Dao (2010) develops a reasonable model to determine credit rating for Vietnamese commercial banks based on the financial data using regression analysis. Bank credit scoring is calculated as:

$$
\begin{aligned}
& \hat{R}_{1 i}=1.857995+9.221743 * R O E_{i}-7.183857 * N P M_{i}-11.26797 * A U_{i}-0.064605 * E M_{i} \\
& -48.83976 * \text { NNIM }_{i}+1.047736 * \text { NNIEX }_{i}
\end{aligned}
$$

where: ROE is Return on Equity, NPM is Net profit margin, AU is Asset utilization, EM is Equity multiplier, NNIM is Net non-interest margin, NNIEX is Non-interest income/Non-interest expense

\section{Credit risk}

Credit risk is the risk of loss of principal or loss of a financial reward from a borrower's failure to repay a loan or meet a financial obligation. For banks, NPL ratio, defined as the ratio of non-performing loans or bad debts to gross loans is a proxy for credit risk. NPL ratio shows the asset quality of a bank and how much proportion of total loans is classified as close to default.

\section{Leverage risk}

Leverage is the use of various financial instruments or borrowed capital, such as margin, to increase the potential return of an investment, or the amount of debt used to finance a firm's assets. A firm with significantly more debt than equity is considered to be highly leveraged. Leverage in banking is far higher than in other industry sectors. For instance, the average leverage ratio across 10 of the world's largest listed non-financial companies is about $50 \%$. That is, on average these companies fund their assets around 50:50 with debt and equity. In banking, however, a more common ratio is 95:5 (Ingves, 2014).

In this paper, leverage risk indicator is calculated by dividing book value of the bank's debts over book value of total assets. 


\subsubsection{Bank-specific Variables}

Banks variables include: NII, TDTA, CAR, PRE and TA.

NII represents the diversification of banks' sources of income, defined as the ratio of non-interest income to gross income. There exists a negative relationship between the diversification of income sources and the bank's risk exposure.

TDTA, the proportion of banks' total deposits over total asset, is used to measure the amount of deposits in a bank's capital structure, or more specifically, the proportion of a bank's assets which are financed through customer deposits.

CAR, Capital Adequacy Ratio, is a measure of the bank's capital. It is expressed as a ratio of a bank's capital (Tier 1 and Tier 2) to its risk weighted assets. Tier I capital composes of Common stock + Retained earnings and Tier II capital composes of Undisclosed Reserves + General Loss reserves + Hybrid debt capital instruments + Subordinated debts

Risk-weighted assets are a bank's assets and off-balance-sheet exposures, weighted according to risk. This ratio is used to protect depositors and promote the stability and efficiency of financial system around the world.

PRE is the ratio of annual deposit insurance premium to total deposits of a bank. Data on banks' annual deposit insurance fee are obtained1 though published documents by Deposit Insurance of Vietnam.

Total asset of banks, TA, is included as a measure of the bank's size. Larger banks are expected to have a greater capability to diversify their risks and stabilize the cash flow from their business. However, they might be incentivized to take more excessive risks due to their systematic importance (too-big-too-fail cases).

ROA, calculated as Net income over Total assets, is an indicator of how profitable a company is relative to its total assets. ROA gives an idea as how efficiently management uses its assets to generate earnings.

ROE, calculated as Net income over Book value of equity, measures the bank's efficiency at generating profits from every unit of shareholder's equity, or in other words, shows how well the bank uses their investment funds to generate earning growth.

\subsubsection{Macroeconomic Variables}

Macroeconomic variables are included to demonstrate the state of the economy. In this research, real interest rate, RINT, and Vietnam real GDP growth rate, GDPG, are taken into consideration.

The real interest rate is the rate of interest an investor expects to receive after allowing for inflation. The real interest rate of an investment is calculated as the amount by which the nominal interest rate is higher than the inflation rate.

\footnotetext{
1 The author would like to thank Ms Pham Bao Khanh for helping us with premium data.
} 
GDP, Gross Domestic Product, is the market value of all officially recognized final goods and services produced within a country in a year, or other given period of time. GDP is commonly used as an indicator of the economic health and the standard of living of a country. GDP annual growth is used in this study as a measure of the country's economic growth.

\subsection{Population and Sample Selection}

This research is set to examine the effect of deposit insurance on banks risk taking in Vietnam, so 31 Vietnamese commercial banks can be considered as the population in selecting a sample for testing. Of these 31 banks, 25 banks are randomly chosen for the sample in this research.

After the selection of sample, consolidated financial data in 4 years, from 2011 to 2014, of 25 banks are collected. The data are limited to 4 years only to better reflect the situation of current banking system.

\subsection{Data Collection}

This data set contains the annual information about 25 banks and Vietnamese macroeconomic data from 2011 to 2014. For independent variables, some bank variables can be collected from banks' financial statement. Meanwhile, the data on deposit insurance premium are obtained from published documents by Vietnam Deposit Insurance. Macroeconomic indicators are from www.econstats.com website.

Regarding risk variables, leverage risk ratio can be easily calculated from banks' balance sheet. For credit risk, the data on banks 'non-performing loans are collected from banks' annual reports and then used to generate ratios of "Non-performing loans/Gross loans" and "Non-performing loans/Total assets".

To compute banks' default probability, 6 financial ratios including ROE, NPM, AU, EM, NNIM and NNIEX are drawn from balance sheets and income statements to calculate banks credit rating. Then these credit rating data are used as input to generate data on banks' default risk indicators ${ }^{2}$.

The resulting sample contains data for 25 banks in 4 years, with a total of 100 observations $^{3}$

\subsection{Empirical Results}

From collected data, Eviews is employed to estimate the equations to show how banks variables and macroeconomic variables affect banks' risk taking.

\subsubsection{The Relationship between Leverage Risk and Deposit Insurance Premium}

The final regression model of leverage risk is:

$$
\begin{aligned}
& \text { Estimated LOG }(\mathrm{LEV})=-1.155-0.0995 * \mathrm{LOG}(\mathrm{PRE})+0.0297 * \mathrm{ROE}(-1)-0.1338 * \mathrm{TDTA}(1) \\
& \text { p-value respectively: } 0.0000,0.0000,0.05136,0.0027
\end{aligned}
$$

\footnotetext{
2 The detailed computed table of default probability can be provided upon request.

${ }^{3}$ The detailed database can be provided upon request.
} 
R-squared: 0.9424, Adjusted R-squared: 0.9094, $\mathrm{n}=75$

There are three variables that are kept in the model of leverage risk. Two out of four variables (LOG(PRE), TDTA) have $\mathrm{p}$-value less than 0.05 . These other variable have $\mathrm{p}$ value larger than 0.05 which show the insignificant impact of $\mathrm{ROE}(-1)$ on leverage risk.

In this model, $\beta$ o equal -1.155 means that holding other variables equal 0 , the leverage risk equal -1.155. It does not have real economic meaning.

The coefficients of LOG(PRE) and TDTA are -0.0995 and -0.1338 ; which illustrate the negative relationship of LOG(PRE) and TDTA with leverage risk. Holding other variables constants, when deposit premium increases by $1 \%$, TDTA increases $1 \%$, leverage risk decline $0.995 \%$ and $0.1338 \%$.

In contrast, ROE (-1) have positive coefficients 0.0297. It means if others variable unchanged, when $\mathrm{ROE}(-1)$ increases $1 \%$, leverage risk also increases by $0.0297 \%$.

R2 equals 0.942 which represents that variables included in this model have strength of $94.2 \%$ in explanation the variation of leverage risk.

\subsubsection{The Relationship between Liquidity Risk and Deposit Insurance}

The final regression model obtained as follows:

$$
\text { Estimated LIQ }=1.504-0.152 * \text { LOG(PRE) }-0.197 * \text { LOG(CAR })+0.587 * \text { ROE }
$$

p-value: $0.0001,0.0023,0.0104,0.0596$

R-squared: 0.5359, Adjusted R-squared: 0.3619, n=100

There are only three variables included in the model of liquidity. Two variables (LOG(PRE) and $\mathrm{LOG}(\mathrm{CAR})$ ) obtain the p-value less than $5 \%$ which show the significant impacts on liquidity risk.

This form of liquidity regression model is chosen after some trial. The estimated equation shows that the constant variable is 1.504 . This means that holding all variables are zero, the liquidity is 1.504 . It does not have real economic meaning.

Variables LOG(PRE) and LOG(CAR) have negative association with liquidity risk. CAR's coefficient is -0.197 , suggest that holding other variables constants, when CAR decrease $1 \%$, liquidity risk increases 0.00197 units on average. LOG(PRE) has coefficient of -0.152 , means that holding others constant, deposit insurance premium increase by $1 \%$, liquidity risk will decline 0.00152 units.

$\mathrm{R}^{2}$ is 0.5359 which illustrates that there is $53.59 \%$ variation in liquidity risk explained by three variables: ROE, CAR and PRE

\subsubsection{The Relationship between Default Risk and Deposit Insurance}

As can be seen from the table, all the variables have $\mathrm{p}$ value smaller than $5 \%$. It is a positive signal that six variables included in this model have significant impact on default risk. 
Estimated LOG(DEF) $=-6.318+0.384 * \mathrm{LOG}(\mathrm{PRE})+0.131 * \mathrm{LOG}(\mathrm{ROA})-3.974 * \mathrm{ROE}$

$$
+3.228 * \mathrm{CAR}-4.715 * \mathrm{NII}-1.241 * \mathrm{TDTA}
$$

p-value: $0.0002,0.0360,0.0395,0.0011,0.0076,0.0000,0.0233$

R-squared: 0.6761, Adjusted R-squared: 0.5354, $\mathrm{n}=100$

The coefficient $\beta_{1}$ is -6.318 means that the value of default risk is -6.318 when all variables hold the value of zero. However, it does not have real economic meaning. LOG(PRE), LOG(ROA) and CAR are three coefficients that link positively to default risk. LOG(PRE) equals 0.384 , means that holding other variables constants, PRE rises 1\%, default risk increases $0.384 \%$. Coefficient of LOG(ROA) equals 0.131 means that an increase of $1 \%$ in ROA, default risk rises by $0.131 \%$. That CAR is 3.228 can be interpreted that when other variables unchanged, $1 \%$ increased of CAR equivalent to $3.228 \%$ rose by default risk on average

There are three negative coefficients, ROE, NII and TDTA. These values are $-3.974,-4.715$ and -1.241 respectively, showing that when ROE, NII and TDTA increase 1 unit, holding other variable constant; default risk declines by $3.974 \%, 4.715 \%$ and $1.241 \%$ on average.

$\mathrm{R}^{2}$ is 0.6761 . It means that $67.61 \%$ variation of default risk can be explained by those variables.

3.5.4 The Relationship between Credit Risk and Deposit Insurance

Estimated CRE $=-0.891+0.096 *$ LOG $($ PRE $)-0.116 *$ LOG $($ TDTA $)+0.070 *$ LOG $($ DEF $)+$

$$
0.370 * \mathrm{ROE}
$$

p-value: $0.0012,0.0096,0.1709,0.0028,0.0687$

R-squared: 0.4186, Adjusted R-squared: 0.1894, n=100

The Eviews table reveals that two out of five variables obtaining the $\mathrm{p}$ value less than $5 \%$ and only variable LOG(TDTA) have p-value larger than $10 \%$. It shows that variables included in this model approximately have significant impacts on credit risk.

The constant coefficient is -0.891 , meaning that when all variables are zero, credit risk is -0.891 . It does not have real economic meaning.

Except for LOG(TDTA), all the other variables have minus coefficient which implies the disproportional relationship of those to credit risk. Coefficient of LOG(TDTA) is -0.116 . This means when other variable constants, TDTA increase $1 \%$, credit risk decreases 0.00116 units.

LOG(PRE), LOG(DEF) and ROE have positive association with credit risk. Coefficient of LOG(PRE) and LOG(DEF) equals 0.096 and 0.07 respectively; therefore, when other variable unchanged, the rise of $1 \%$ in PRE, DEF lead to the rise of 0.00096 units and 0.0007 units in credit risk.

Coefficient of ROE is 0.37 , means that holding other variables constant, when ROE increases $1 \%$, credit risk increases by $0.37 \%$. 
$\mathrm{R}^{2}$ is 0.4186 , which represent that there is $41.86 \%$ variation in credit risk explained by these variables.

\section{Discussion and Conclusion}

The relationship of deposit insurance scheme and risk taken by bank is assessed through four models about liquidity risk, leverage risk, default risk and credit risk. The regression functions are established after functional form, redundant test. It means significance of variables is examined to find the most appropriate model for each type of risk. After error checking, there is no multicollinearity, heteroscedasticity and autocorrelation issue existing in four risk models.

Equations (1), (2), (3) and (4) demonstrate the estimation results of leverage risk, liquidity risk, credit risk and default risk with seven variables, in which six variables are bank's characteristic, one variable is default risk which is assessed the connection with credit risk.

Results released not totally consensus with major conclusion of previous studies that deposit insurance increases banking risk.

The table illustrates the both positive and negative coefficients of deposit premium with bank's risk. It indicates that there are both positive and negative associations with deposit insurance premium among banking risks. Specifically, leverage risk and liquidity risk have negative relationship with level of deposit insurance premium. In contrast, it is positive with default risk and credit risk. It implies that the higher deposit insurance premium, the higher credit risk and default risk, while leverage risk and liquidity risk are less.

Results suggest that amount of deposit insurance premium has a positive and significant effects on credit risk. The positive relationship between deposit insurance premium and credit risk supports to moral hazard theory. Banks recognize deposit premium as a cushion for losses; therefore, deposit premium encourages banks to involve in higher risk. Bank may accept the low quality loans by loosening their screening and monitoring the loans, taking more risky investments. Higher risk taking means higher potential of loss. Hence, provision for loans losses increase, leading to the increase in credit risk.

The relationship between default risk and deposit insurance also can be explained based on moral hazard argument. Higher insured deposit make bank more willing to give out the loans. Simultaneously, loan assessment is less tightening. That decreases the probability of repayment loan's obligation. Besides, as can be seen obviously from table 4, credit risk and default risk link positively to each other. Therefore, credit risk and default risk should have same relationship with deposit insurance premium.

The p-value in both credit risk and default risk model is significant which is much smaller than 0.05 . It refers to the high accuracy conclusion of research's findings.

On contrary, leverage risk and liquidity risk will be reduced if amount of deposit insurance premium increase. In term of liquidity risk, it is understandable that deposit insurance premium discourages liquidity risk. As mentioned above, liquidity risk happens when bank in the lack of cash or liquid assets to meet the unexpected need. The lower fund is reserved, the 
higher potential risk bank may face with. Once involving in deposit insurance premium, banks have obligation to government to keep a certain amount of premium; which can meet the unexpected withdraw. Therefore, probability of liquidity risk is reduced. As the p-value is $0.3 \%$, it can be concluded that deposit insurance premium significantly influences liquidity risk.

Leverage risk is found to be negative linked to the change in deposit insurance premium. It means when amount of deposit premium is lower, leverage risk becomes higher. However, the p-value of variable PRE is larger than 0.05 which indicates the insignificant impact of deposit insurance premium on leverage. In facts, previous researches found different conclusion in aspect of leverage risk and deposit premium. Wheelock \&Wilson, (1994) discovered that banks with higher fund reserved will be more willing to have higher leverage capital structure; hence facing higher potential of risk. In 2004, Gropp and Vesala also find the similar conclusion.

Generally, the results released by this research may have some unconsents with several previous studies. Researches normally are conducted in different countries as well as different time. There are many different factors like scope, financial policies, premium coverage, which may affect the research result.

The connection between deposit insurance and behavior of banks in taking risk has been explored widely in global scope. This paper is conducted on purpose of finding the relationship of deposit insurance and banking risk of commercial banks in Vietnam. Research reveals the result that deposit insurance does influence on risk taking by banks. Specifically, when deposit insurance premium increases, leverage risk and liquidity risk are lower; in contrast, credit risk and default risk are higher.

\section{References}

Allen, F., Carletti, E., \& Leonello, A. (2011). Deposit insurance and risk taking. Oxford review of economic policy. pp. 464-478. https://doi.org/10.1093/oxrep/grr022

Angkinand, A., \& Wihlborg, C. (2010). Deposit Insurance Coverage, Ownership, and Banks' Risk-Taking in Emerging Markets. Journal of International Money and Finance, 29(2), 252-274. https://doi.org/10.1016/j.jimonfin.2009.08.001

Boot, A., \& Greenbaum, S. (1993). Bank-Regulation, Reputation and Rents: Theory and Policy Implications. Cambridge University Press, Cambridge.

https://doi.org/10.1017/CBO9780511752056.017

Dao, B. (2011). Vietnamese Commercial Banks Ratings. Thesis, Hanoi University.

Dao, B., \& Dang, T. (2010). Credit scoring model for manufacturing Vietnamese company 2010. Thesis, Hanoi University.

Davis, E., \& Obasi, U. (2009). Deposit insurance systems and bank risk. Working Paper, Brunel University.

Demirguc-Kunt, A., \& Detragiache, E. (2000). Does deposit insurance increase banking 
system stability? An empirical investigation. Journal of Monetary Economics, 49(7), 1373-1406. https://doi.org/10.1016/S0304-3932(02)00171-X

Demirguc-Kunt, A., \& Kane, E. (2002). Deposit insurance around the globe: Where does it work?. Journal of Economic Perspectives, American Economic Association, 16(2), 175-195. https://doi.org/10.1257/0895330027319

Demirguc-Kunt, A., \& Sobaci, T. (2001). Deposit Insurance Around the World: A Data Base. The World Bank Economic Review, 15(3), 480-490. https://doi.org/10.1093/wber/15.3.481

Diamond, D., \& Dybvig, P. (1983). Bank Runs, deposit insurance and liquidity. Journal of Political Economy, 91(3), 401-419. https://doi.org/10.1086/261155

Enkhbold, E. (2013). The effect of deposit insurance on risk taking in Asian banks. Asian Journal of Finance \& Accounting, 5(1). https://doi.org/10.5296/ajfa.v5i1.3023

Gropp, R., \& Vesala, J. (2004). Deposit insurance, moral hazard and market monitoring. Review of Finance, 8(4), 571-602. https://doi.org/10.1093/rof/8.4.571

Ingves, S. (2014). Banking in leverage. Speech, 10th Asia-Pacific High-Level Meeting on Banking Supervision, Auckland, New Zealand.

International Association of Deposit Insurers. [Online] Available:

http://www.iadi.org/default.aspx

Schich, S. (2009). Financial crisis: deposit insurance and related financial safety net aspects. OECD Journal: Financial Market Trends, 2008(2), 1-39.

https://doi.org/10.1787/fmt-v2008-art12-en

\section{Appendix}

Appendix 1. A summary of the relationship between banks' risks and deposit insurance

\begin{tabular}{|l|l|l|l|l|}
\hline Variables & LOG(LEV) & LIQ & LOG(DEF) & CRE \\
\hline CAR & & & $\begin{array}{l}3.228355 \\
(0.0076)\end{array}$ & \\
\hline LOG(CAR) & & -0.1969 & & \\
& & $(0.0104)$ & & \\
\hline NII & & & $\begin{array}{l}-4.715069 \\
(0.0000)\end{array}$ & \\
\hline PRE & & & & \\
\hline LOG(PRE) & 0.0995 & -0.1521 & 0.384243 & 0.096034 \\
& $(0.0000)$ & $(0.0023)$ & $(0.0360)$ & $(0.0096)$ \\
\hline ROA & & & & \\
\hline LOG(ROA) & & & 0.131297 & \\
& & & $0.0395)$ & \\
\hline ROE & & 0.5870 & -3.974003 & 0.370639 \\
\hline
\end{tabular}




\begin{tabular}{|c|c|c|c|c|}
\hline & & $(0.0596)$ & $(0.0011)$ & $(0.0687)$ \\
\hline ROE(-1) & $\begin{array}{l}0.0297 \\
(0.5136)\end{array}$ & & & \\
\hline TDTA & $\begin{array}{l}-0.1338 \\
(0.0027)\end{array}$ & & $\begin{array}{l}-1.241125 \\
(0.0233)\end{array}$ & \\
\hline LOG(TDTA) & & & & $\begin{array}{l}-0.116925 \\
(0.1709)\end{array}$ \\
\hline LOG(DEF) & & & & $\begin{array}{l}0.070720 \\
(0.0028)\end{array}$ \\
\hline \multicolumn{5}{|l|}{ GDPG } \\
\hline \multicolumn{5}{|l|}{ LOG(GDPG) } \\
\hline \multicolumn{5}{|l|}{ RINT } \\
\hline $\mathbf{R}^{2}$ & 0.9424 & 0.52359 & 0.676165 & 0.418637 \\
\hline Adjusted $\mathbf{R}^{2}$ & 0.9093 & 0.3619 & 0.535368 & 0.189367 \\
\hline
\end{tabular}

\section{Copyright Disclaimer}

Copyright for this article is retained by the author(s), with first publication rights granted to the journal.

This is an open-access article distributed under the terms and conditions of the Creative Commons Attribution license (http://creativecommons.org/licenses/by/4.0/). 